\title{
Characterization of Cowpea aphid-borne mosaic virus in Passiflora edulis 'Catarina' in the southern coast of Santa Catarina State, Brazil
}

\section{Caracterização do Cowpea aphid-borne mosaic virus em Passiflora edulis cv. Catarina no litoral sul de Santa Catarina, Brasil}

\author{
Addolorata Colariccio ${ }^{1 *}$ (1) (orcid.org/0000-0002-4948-1664) \\ Leilane Karam Rodrigues ${ }^{1}$ (orcid.org/0000-0001-6492-6505) \\ Alyne de Fátima Ramos ${ }^{1}$ (orcid.org/0000-0001-6089-1886) \\ Alexandre Levi Rodrigues Chaves ${ }^{1}$ (D) (orcid.org/0000-0002-5580-0932) \\ Marcelo Eiras ${ }^{1}$ (D) (orcid.org/0000-0001-7901-9107) \\ Ricardo Harakava' (D) (orcid.org/0000-0003-1431-2665) \\ Luiz Augusto Martins Peruch² (D) (orcid.org/0000-0003-0158-0257)
}

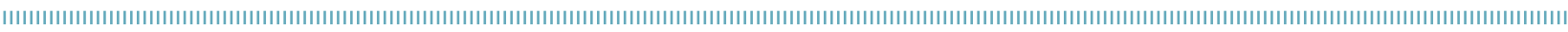

\begin{abstract}
CABMV is a limiting virus for passion fruit crop in Brazil, its main producing country. This virus has been reported in all producing states of the country, with the state of Santa Catarina (SC) in 2017 standing as the third largest passion fruit producer. In 2017, it reached $8.4 \%$ of the national production. The southern coast is the main responsible for the increase in production, which has been supplying the domestic market. However, in that same year, this region recorded the first symptom expressions in plants and fruits. The evaluation of the samples collected in the municipalities of Sombrio, Praia Grande and São João do Sul, southern coast of SC, was performed by using a mechanical transmission to indicator plants, PTA-ELISA and RT-PCR, and by sequencing. The evaluation results were positive for CABMV and negative for CMV in PTA-ELISA. In RT-PCR, there was the formation of a 700bp ca band, expected size for Potyvirus, whose sequence comparison with those deposited in GenBank reveled 98\% identity with the isolates from Sáo Paulo State. The occurrence of the virus in the southern coast of SC did not reach a serious decrease in passion fruit production due to the union of producers, who adopted preventive management measures to control the virus, whose effect led to a consolidation of the passion fruit production chain in the region.
\end{abstract}

KEYWORDS: identification; yellow passion fruit; productivity; Potyvirus.
RESUMO: O CABMV é um vírus limitante para a cultura do maracujá no Brasil, principal país produtor mundial, cuja ocorrência já foi relatada em todos os estados produtores. Em 2017, o estado de Santa Catarina (SC) foi o terceiro maior produtor de maracujá no Brasil, responsável por $8,4 \%$ da produção nacional, sendo o litoral sul o principal responsável pelo aumento da produção, garantindo o abastecimento do mercado interno. Entretanto, nesse mesmo ano, essa regiáo registrou as primeiras expressóes de sintomas em plantas e frutos. Uma avaliação das amostras coletadas nos municípios de Sombrio, Praia Grande e São João do Sul, litoral sul de Santa Catarina, foi realizada por transmissão mecânica para plantas indicadoras, PTA-ELISA, RT-PCR e sequenciamento. Os resultados foram positivos para o CABMV e negativos para o CMV, tanto em PTA-ELISA quanto RT-PCR. Na RT-PCR, houve a amplificação de bandas com ca de $700 \mathrm{pb}$, tamanho esperado para o Potyvirus cuja comparaçáo de sequências com as depositadas no GenBank revelaram 98\% de similaridade com os isolados do estado de São Paulo. A ocorrência do vírus na região do litoral sul de Santa Catarina náo causou quebra na produção de maracujá devido à adoção conjunta de medidas preventivas de manejo pelos produtores, fato que consolidou a cadeia produtiva do maracujá na região.

PALAVRAS-CHAVE: identificação; maracujá amarelo; produtividade; Potyvirus. 
The center of origin for the Passifloraceae is Brazil, with approximately 200 species. Passiflora edulis Sims "yellow passion fruit" is the main species commercially grown, and some viruses have already been described in this species. Among them: Passion fruit vein clearing virus (PVCV); Passion fruit yellow mosaic virus (PFYMV); Passion fruit green spot virus (PFGSV); Passion fruit leaf mosaic virus (PLLMV); Passion fruit severe leaf distortion virus (PFSLDV); Passion fruit greenspot virus; Purple granadilla mosaic virus (PGMV); Cucumber mosaic virus (CMV); and Cowpea aphid-borne mosaic virus (CABMV) (FISCHER; RESENDE, 2008; COLARICCIO et al., 2018). However, the most damaging species is CABMV, a virus species that belongs to Potyvirus genus and Potyviridae family and occurs in all producing regions of the world. The CABMV isolates cause important losses in passion fruit crops, due to severe fruit hardening symptoms in all producing regions (CAVICHIOLI et al., 2011; COLARICCIO et al., 2018).

In Brazil, the passion fruit culture has a wide commercial spectrum, ranging from fresh fruit and processed juice to medical and ornamental consumption segments. Among the major challenges for passion fruit production, the occurrence of virus-induced diseases is one of the most significant, mainly due to control difficulties. The first occurrence of CABMV in Brazil was report in Bahia State (CHAGAS et al., 1981), but the disease spread throughout the main producing regions of the country (KITAJIMA, 1999; RODRIGUES et al., 2015; COLARICCIO et al., 2018).

In Santa Catarina (SC), CABMV was identified in passion fruit from the northern coast with the PTA-ELISA and the visualization of cylindrical inclusions in electron microscopy (COLARICCIO et al., 2008). Given the control difficulties of CABMV in the crop, producers abandoned the cultivation of passion fruit in the northern region of SC. In SC, the culture migrated to the southern part of the state, where it again gained importance with the cultivar Catarina (PERUCH et al., 2018). However, a few years later, a high incidence of plants showing CABMV symptoms was detected in passion fruit fields, causing up to $20 \%$ yield reduction in both fruit quality and productivity.

Considering that passion fruit cultivation is an income alternative for many producers in the southern and northern regions of Santa Catarina, the monitoring of cultivated areas cannot be neglected. The CABMV is transmitted and disseminated by some species of aphids (Homoptera: Aphididae), in a non-persistent manner, to passiflora. Although there is not a species colonizing passiflora, many species have been described for transmitting CABMV, mainly: Myzus persicae Shulzer; Aphis gossypii Glover; A. fabae Scopoli; A. craccivora Bock.; Toxoptera citricidus Kilkaldy; Uroleucon ambrosiae Thomas; U. sonchi L.; and Myzus nicotianae Blackman (GARCÊZ et al., 2015; RODRIGUES et al., 2016). Leaves of $P$. edulis, 'Catarina', with severe blistering and mosaic were collected in Sombrio, Praia Grande and São João do Sul municipalities (Figs. 1A and 1B), located in the southern coast of Santa Catarina State. The samples were evaluated by mechanical transmission to several host plants, to PTA-ELISA with the antiserum against CMV and CABMV, and also by RNA extraction, RT-PCR with primers designed to anneal to the genomic regions of potyvirus CI (HA et al., 2008) and sequencing. The results of mechanical transmission were positive to CABMV, with local chlorotic lesions in Chenopodium amaranticolor and mosaic in Nicotiana rustica. In PTA-ELISA, CMV was negative and CABMV positive. By RT-PCR, fragments with ca. 700bp of the samples were sequenced and deposited in GenBank with the numbers: CABMV-1 (MG661264); CABMV-2 (MG661265), CABMV-3 (MG661266), CABMV-4 (MG661267), CABMV-5 (MG661268). The comparisons among our sequences and the sequences deposited in the GenBank showed a high similarity with the CABMV Brazilian isolates. There was no difference between the varieties of samples or their geographical origin, revealing $98 \%$ of similarity with CABMV passion fruit isolates from São Paulo State (RODRIGUES et al., 2015).

Seen that there is not an effective chemical control of the CABMV in this culture, it is important to strengthen measures based on cultivation practices to reduce the loss caused by the CABMV in passion fruit crops. Several actions were developed in search of genotypes with higher resistance levels in relation to the main diseases. Until today, there is little information on virus resistance, except for the cultivars EMBRAPA, 'BRS Sol Cerrado', BRS Ruby Cerrado, BRS Pearl Cerrado, BRS Red Gold which are considered tolerant to anthracnose, bacteriosis and viruses (PIRUCH et al., 2018). Due to the difficulty in obtaining the effective resistant cultivars, producers may take preventive measures. Among them, early detection of CABMV, elimination of plants with symptoms and complete eradication of the crop at the end of the cycle, producing a 30-day sanitary emptiness with the objective of preventing the virus spread in the region and keep passion fruit production from being affected in the presence of the virus.
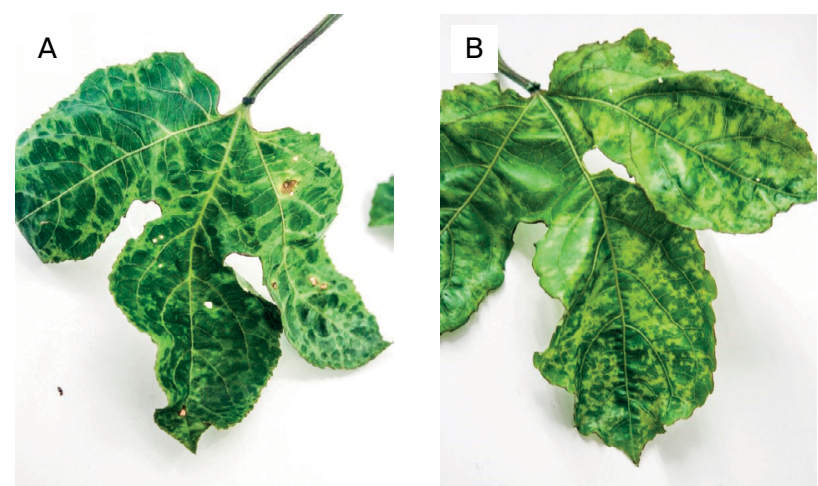

Figure 1. Samples of yellow passionfruit leaves of 'Catarina' collected in Sombrio, Santa Catarina State, with symptoms of blistering (A) and mosaic (B). 
ACKNOWLEDGEMENTS: This study was financed in part by the Coordenação de Aperfeiçoamento de Pessoal de Nível Superior - Brasil (CAPES) - Finance Code 001, and Fundação de Amparo à Pesquisa do Estado de São Paulo - FAPESP (Proc. 2011/11/96-95).

FUNDING: This study was funded by FAPESP (Proc. 2011/11796-5).

CONFLICTS OF INTEREST: The authors certify that they have no commercial or associative interest that represents a conflict of interest in connection with the manuscript.

ETHICAL APPROVAL: Not applicable.

AVAILABILITY OF DATA AND MATERIAL: All data generated or analyzed during this study are included in this published article. The datasets generated and/or analyzed during the current study are available in the GenBank (https://www.ncbi. nlm.nih.gov/genbank/)

AUTHORS' CONTRIBUTIONS: Conceptualization: COLARICCIO, A.; PERUCH, L.A.M. Data curation: COLARICCIO, A.; CHAVES, A.L.R. Formal analysis: COLARICCCIO, A.; RODRIGUES, L.K. Methodology: RAMOS, A.A.; RODRIGUES, L.K.; CHAVES, A.L.R.; EIRAS, M. Writing - original draft: COLARICCIO, A. Writing - review and editing: COLARICCIO, A.; CHAVES, A.L.R,; EIRAS, M.

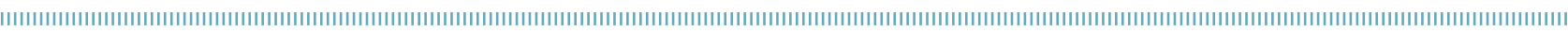

\section{REFERENCES}

COLARICCIO, A.; PERUCH, L.A.M.; GALLETI, S.R.; LOMBARDI, R.; CHAGAS, C.M. $O$ endurecimento dos frutos do maracujazeiro associado a severas perdas no Litoral Norte de Santa Catarina, Brasil. Tropical Plant Pathology, v.33 (Suplemento), 2008.

COLARICCIO, A.; GARCÊZ, R.M.; RODRIGUES, L.K.; EIRAS, M.; PERUCH, L.A.M.; CHAVES, A.L.R. Doenças causadas por vírus na cultura do maracujazeiro (Passiflora edulis). In: PERUCH, L.A.M.; SCHROEDER, A.L. (Eds.). Maracujazeiroazedo: polinização, pragas e doenças. $1^{\text {a }}$ ed. Florianópolis: EPAGRI, 2018. p.171-202.

CAVICHIOLI, J.C.; CORRÊA, L.S.; NARITA, N.; KASAI, F.S. Incidência e severidade do vírus do endurecimento dos frutos em maracujazeiros enxertados em pé-franco. Revista Brasileira de Fruticultura, Jaboticabal, v.33, n.spe 1, p.411-414, 2011 . https://doi.org/10.1590/ so $100-29452011000500053$

CHAGAS, C.M.; KITAJIMA, E.W.; LIN, M.T.; GAMA, M.I.C.S.; YAMASHIRO, Y. Grave moléstia do maracujá amarelo (Passiflora edulis f. flavicarpa, Deg.) no Estado da Bahia causado por um isolado do vírus "woodiness" do maracujá. Fitopatologia Brasileira, Brasília, v.6, n.2, p.259-268, 1981.

EDWARDSON, J.R.; CHRISTIE, R.G.; KO, J.N. Potyvirus cylindrical inclusions- subdivision IV. Phytopathology, v.74, p.1111-1114, 1984. https://doi.org/10.1094/phyto-74-1111

FISCHER, I.H.; RESENDE, J.A.M. Diseases of passion flower (Passiflora spp.). Pest Technology, Kagawa, v.2, n.1, p.119, 2008.
GARCÊZ, R.M.; CHAVES, A.L.R.; EIRAS, M.; MELETTI, L.M.M.; DE AZEVEDO FILHO, J.A.; DA SILVA, L.A.; COLARICCIO, A. Survey of aphid population in a yellow passion fruit crop and its relationship on the spread Cowpea aphid-borne mosaic virus in a Subtropical region of Brazil. SpringerPlus, v.4, p.537, 2015. https://doi.org/10.1186/ s40064-015-1263-5

HA, C.; COOMBS, S.; REVILL, P.A.; HARDING, R.M.; VU, M.; DALE, J.L. Design and application of two novel degenerate primer pairs for the detection and complete genomic characterization of potyviruses. Archives of Virology, v.153, n.1, p.25-36, 2008. https://doi.org/10.1007/s00705-007-1053-7

KITA JIMA, E.W. Viroses de fruteiras tropicais no Brasil. Fitopatologia Brasileira, v.25, n.1, p.34-41, 1999

PERUCH, L.A.M; COLARICCIO, A.; BATISTA, D.C. Controle de doenças do maracujazeiro: situação atual e perspectivas. Revista Agropecuária Catarinense, v.31, n.1, p.37-40, 2018. http:// dx.doi.org/10.22491/RAC.2018.v31n 1.2

RODRIGUES, L.K.; SILVA, L.A.; GARCÊZ, R.M.; CHAVES, A.L.R.; DUARTE, L.M. L.; GIAMPANI, J.S. COLARICCIO, A.; HARAKAVA, R.; EIRAS, M. Phylogeny and recombination analysis of Brazilian yellow passion fruit isolates of Cowpea aphid-borne mosaic virus: origin and relationship with hosts. Australasian Plant Pathology, v.44, n. 1, p.31-41, 2015. https://doi.org/10.1007/s13313-014-0308-5

RODRIGUES, L.K.; CHAVES, A.L.R.; DAMATTO JUNIOR, E.R.; EIRAS, M. Epidemiological aspects of the transmission and management of cowpea aphid-borne mosaic virus in a passion fruit orchard. Journal of Plant Pathology, v.98, n.3, p.53 1-539, 2016. https:// doi.org/10.4454/JPP.V9813.037 